\title{
OPTIMASI PEMBAGIAN TUGAS KARYAWAN MENGGUNAKAN METODE HUNGARIAN (Studi Kasus : Karyawan Grand Sony Tailor Makassar)
}

\author{
Risnawati Ibnas ${ }^{\mathrm{i}}$, Irwan ${ }^{\mathrm{ii}}$, Nur Huda Nur Wirum ${ }^{\mathrm{iii}}$
}

\author{
${ }^{i}$ Univesitas Islam Negeri Makassar,risnawati.ibnas@uin-alauddin.ac.id \\ ii Universitas Islam Negeri Makassar, \\ iii Mahasiswa Program Studi Matematika-FST, UINAM
}

\begin{abstract}
ABSTRAK, Program linear yang dapat dijumpai dalam kehidupan sekitar adalah masalah penugasan (assignment problem). Masalah umum penugasan meliputi $n$ tugas yang harus ditetapkan kepada m pekerja dengan asumsi setiap pekerja memiliki kompetensi yang berbeda dalam menyelesaikan setiap tugas. Salah-satu metode dalam menyelesaikan dengan masalah ini adalah metode Hungarian. Tujuan dari penelitian ini adalah untuk mengoptimalkan penugasan karyawan dengan melihat dari segi biaya operasional minimum dan waktu penyelesaian minimum pekerjaan dengan menggunakan metode Hungarian. Dari hasil penelitian, diperoleh waktu penyelesaian menjahit pakaian pada Grand Sony Tailor yaitu 39 jam, dimana terjadi efisiensi waktu sebanyak 4 jam jika dibandingkan waktu penyelesaian sebelum menggunakan metode Hungarin yaitu selama 43 jam. adapun untuk biaya produksi yang dikeluarkan perusahaan melihat dari penempatan tugas karyawan dengan waktu penyelesaian optimum yaitu $R p$ 4.925.500,00dengan keuntungan perusahaan $R p$ 1.624.750,00 dalam menyelesaikan 10 jenis pakaian.
\end{abstract}

Kata Kunci:Riset Operasi, Program Linear, Metode Hungarian, Optimasi Biaya Produksi.

\section{PENDAHULUAN}

Manajemen produksi sering menghadapi masalah-masalah yang berhubungan dengan alokasi optimal dari berbagai macam sumber daya yang produktif, terutama tenaga kerja. Masalah ini disebut masalah penugasan (Assignment Problem), yang merupakan suatu kasus khusus dari masalah linear.

Masalah penugasan bermula dari penempatan para pekerja pada bidang yang tersedia dalam suatu industri sesuai dengan kompetensi agar biaya yang ditanggung perusahaan dapat diminimalkan. Jika pekerja(Assignee) dianggap sebagai sumber dan pekerjaan (Assignment) dianggap sebagai tujuan, maka model penugasan akan sama dengan masalahtransportasi, dimana jumlah sumber dan tujuan sama, setiap sumber hanya menghasilkan satu demikian pula setiap tujuan hanya memerlukan satu.Dari beberapa sumber yang menjelaskan tentang metode pemecahan masalah penugasan, untuk mendapatkan solusi yang paling optimal yaitu dengan menggunakan metode Hungarian.

Keuntungan terbesar penggunaan metode Hungarian adalah metode yang digunakan dalam memecahkan masalah sangat efisien dari segi efisiensi iterasinya.

Dalam penelitian sebelumnya, yakni penelitian dari Jimi Priyo Assiddiq. Hasil penelitian bahwa dari perhitungan optimalisasi menggunakan metode Hungarian menunjukkan bahwa mendapatkan hasil optimal dibandingkan dengan menggunakan metode perhitungan yang biasa digunakan perusahaan.

Grand Sony Tailor merupakan salah satu tempat bisnis penjahit terkenal di kawasan Makassar. Biaya operasional yang dikeluarkan oleh perusahaan selama ini sebanyak Rp 80 juta per bulannya dengan waktu kerja setiaphari Senin Sabtu yang dimulai pada pukul 09.00 pagi sampai dengan pukul 17.00 sore. Pada Grand Sony Tailor masalah yang selama ini adalah dalam setiap pekerja biasanya memiliki kemampuan yang sama tetapi biaya dan waktu operasi yang berbeda-beda. Maka dari itu perlu adanya perhitungan penempatan kerja yang tepat untuk menugaskan karyawan-karyawan menjahit. Mengetahui akan pentingnya proses penugasan yang tepat, maka menarik bagi peneliti untuk melakukan evaluasi Karyawan Grand Sony Tailor untuk mencari solusi agar biaya dan waktu pengoperasiannya menjadi optimal.

\section{RUMUSAN MASALAH}

Masalah yang akan diselesaikan dalam artikel ini adalah bagaimana hasil optimal penugasan karyawan dari waktu penyelesaian minimum pekerjaan dan biaya produksi minimum dengan menggunakan metode Hungarian? 


\section{TUJUAN PENELITIAN}

Dengan adanya permasalahan yang muncul, maka tujuan dari penelitian ini adalahUntuk mengetahui hasil optimalisasi penugasan karyawan dengan melihat dari waktu penyelesaian minimum pekerjaan dan biaya produksi minimum dengan menggunakan metode Hungarian?

\section{TINJAUANPUSTAKA}

\section{RISET OPERASI}

Riset Operasi adalah metode untuk memformulasikan dan merumuskan permasalahan sehari-hari baik mengenai bisnis, ekonomi, sosial maupun bidang lainnya ke dalam pemodelan matematis untuk mendapatkan solusi yang optimal. ${ }^{5}$

\section{PROGRAM LINEAR}

Linear Programming merupakan alat analisis yang menunjang keberhasilan riset operasi dalam memecahkan berbagai masalah sehingga dapat diambil suatu keputusan yang tepat,

Model matematis pemrograman linear :

Fungsi tujuan :

Maksimumkan/minimumkan

$Z=$

$\sum C_{j} \cdot x_{j}$

(2.1)

Terhadap fungsi kendala-kendala

$$
\begin{aligned}
& a_{11} x_{1}+a_{12} x_{2}+\ldots+a_{1 n} x_{n} \geq \text { atau } \\
& \leq b_{1} \\
& a_{21} x_{1}+a_{22} x_{2}+\ldots+a_{2 n} x_{n} \geq \text { atau } \\
& \leq b_{2} \\
& \vdots \quad \vdots \quad \vdots \quad \geq \text { atau } \leq \text { : } \\
& a_{m 1} x_{1}+a_{m 2} x_{2}+\ldots+a_{m n} x_{n} \quad \geq \text { atau } \\
& \leq b_{m} \\
& x_{j}, \quad \geq 0
\end{aligned}
$$

dimana,

$X_{j}$ : Variabel keputusan ke-j

$C_{j}$ : parameter fungsi tujuan ke-j

$b_{i}$ : kapasitas kendala ke- $i$

$a_{i j}$ : parameter fungsi kendala ke- $i$ untuk variable keputusan ke-j

$i: 1,2, \ldots, m$

$j: 1,2, \ldots, n$.

\section{PERSOALAN PENUGASAN}

Masalah penugasan (assignment problem) adalah suatu masalah mengenai pengaturan objek untuk melaksanakan tugas, dengan tujuan meminimalkan biaya, waktu, jarak, dan sebagainya ataupun memaksimalkan keuntungan.

Masalah penugasan merupakan jenis khusus programming linear dimana sumber-sumber dialokasikan kepada kegiatan-kegiatan atas dasar satu-satu (one-to-one basis). Jadi, setiap sumber atau petugas (assignee) (misalnya, karyawan, mesin, atau satuan waktu) ditugaskan secara khusus kepada suatu kegiatan atau tugas (misalnya suatu pekerjaan, lokasi, atau kejadian). Ada suatu biaya $C_{i j}$ yang berkaitan dengan petugas $i(i=1,2, \ldots, m)$ yang melakukan tugas $j$ $(\mathrm{j}=1,2, \ldots, n)$, sehingga tujuannya ialah untuk menentukan bagaimana tugas harus dilakukan untuk meminimumkan biaya.

Oleh karena itu, bentuk umum model matematis penugasan adalah :

Maksimumkan/minimumkan :

$\min \sum_{i=1}^{m} \sum_{j=1}^{n} C_{i j} X_{j}$

$\sum_{j=1}^{n} X_{i j}=1, \quad$ untuk $j=1,2, \ldots, n$

$\sum_{i=1}^{m} X_{i j}=1, \quad \quad$ untuk $i=1,2, \ldots, m^{14}$

dimana,

$X_{i j}$ : satuan barang yang akan dicari

$C_{i j}$ : Nilai konstribusi objek $i$ terhadap tugas $j$

$S_{i}$ : kapasitas sumber ke-i

$T_{i}$ : permintaan tujuan ke-j

\section{METODE HUNGARIAN}

Algoritma metode Hungarian adalah sebagai berikut:

1. Menyusun tabel penugasan. Letakkan pekerjaan sebagai baris dan pekerja (mesin) sebagai kolom). Jumlah baris sama dengan jumlah kolom, untuk memenuhi asumsi. Jika tidak sama maka diperlukan dummy.

2. Untuk setiap baris, kurangkan semua nilai dengan dengan nilai terbesar (untuk kasus maksimasi) atau nilai terkecil (untuk kasus minimasi) yang ada pada baris tersebut. 
3. Periksa kolom, jika ada kolom yang belum memiliki nilai nol, maka semua nilai pada kolom tersebut dikurangi dengan nilai terkecil yang ada pada kolom yang bersangkutan.

4. Periksa apakah solusi layak sudah optimum. Pemeriksaan dilakukan dengan menggambarkan garis-garis vertikal dan horizontal yang melewati nilai nol. Jika jumlah garis yang terbentuk sama dengan jumlah baris/kolom maka solusi layak optimal sudah diperoleh.

Jika solusi layak optimal belum diperoleh, kurangkan semua nilai yang tidak dilewati garis dengan nilai terkecil, dan tambahkan nilai terkecil tersebut pada nilai yang terletak pada perpotongan garis. Nilai lainnya (yang dilewati garis tapi tidak terletak pada perpotongan) tidak berubah, Kembali ke langkah keempat.

Dapat digambarkan dalam tabel 2.1 matriks penugasan

Tabel 2.1. Matriks penugasan

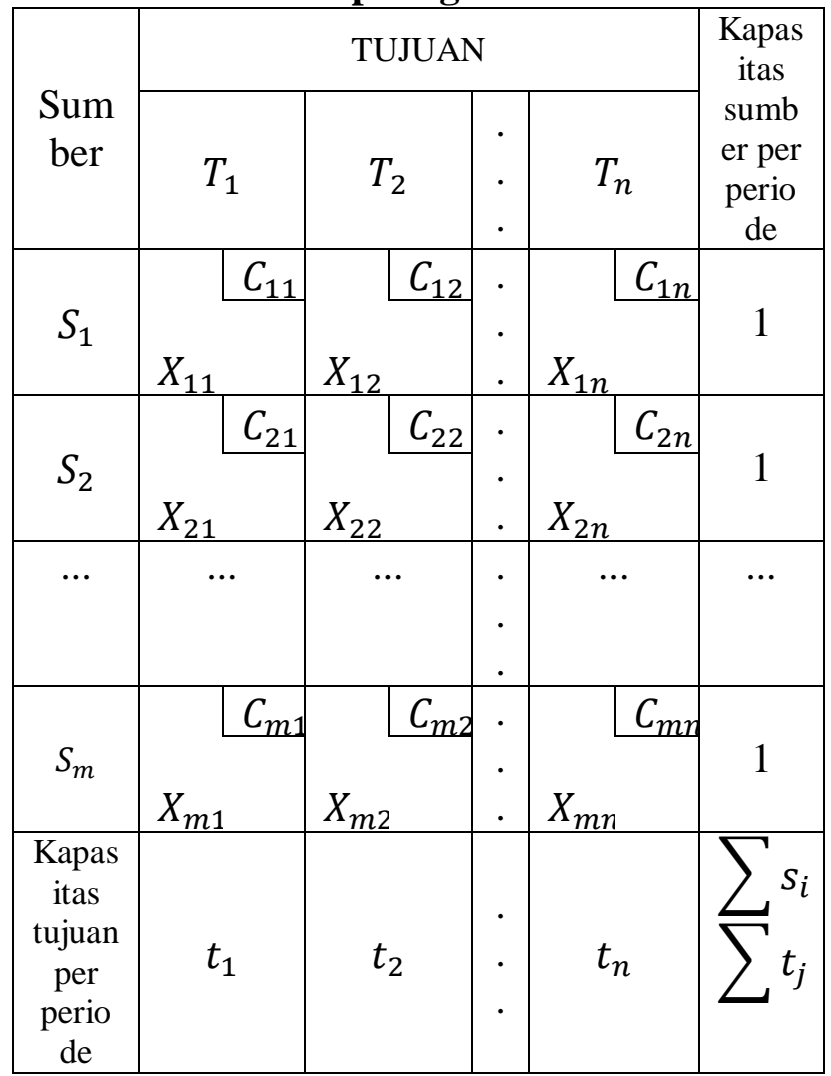

Dimana $X_{i j}=0$ bila tidak ada pekerjaan/kegiatan $X_{i j}=1$ bila ada pekerjaan/kegiatan.

$X_{i j}=$ penugasan dari sumber $i$ ketujuan $j$

$C_{j}=$ satuan ukur dari sumber $i$ ketujuan $j$.

\section{METODOLOGI}

\section{JENIS PENELITIAN}

Jenis penelitian yang digunakan dalam penelitian ini adalah penelitian terapan.

\section{JENIS DAN SUMBER DATA}

Jenis data yang digunakan pada penelitian ini adalah data sekunder. Data yang diambil dari perusahaan berupa data jumlah karyawan khususnya bagian menjahit, jenis pekerjaan, biaya operasi, dan waktu penyelesaian pekerjaan. Sumber Data yang digunakan pada penelitian ini bersumber dari Grand Sony Tailor Makassar yaitu pada bagian karyawan menjahit.

\section{VARIABEL \\ DAN \\ OPERASIONAL VARIABEL}

Adapun variabel yang digunakan dalam penelitian ini yaitu :

a. Biaya operasional, dimana biaya operasional ini adalah sejumlah biaya untuk menjahit/memproduksi setiap jenis pakaian pakaian oleh perusahaan

b. Waktu, dimana waktu ini adalah sejumlah waktu yang digunakan karyawan untuk menyelesaikan setiap jenis pakaian

\section{Prosedur Analisis}

1. Menghitung biaya optimal dengan meninimumkan biaya operasi yang dikeluarkan dengan langkah-langkah :

a. Menyusun tabel penugasan. Dimana jenis pekerjaan sebagai baris dan pekerja (karyawan) sebagai kolom.

b. Untuk setiap baris, kurangkan biaya terendah dalam tiap baris pada tabel biaya tertentu dari semua biaya dalam baris tersebut. Secara matematis bisa ditulis, untuk tiap $i$ maka :

$$
C_{i j}-\min \left(C_{i j}\right), j=1,2, \ldots, n
$$

c. Untuk setiap kolom, kurangkan biaya terendah dalam tiap kolom tabel yang diperoleh dari langkah pertama dari semua biaya dalam kolom tersebut. Secara matematis bisa ditulis, untuk tiap $i$ maka :

$$
C_{i j}-\min \left[C_{i j}\right], i=1,2, \ldots, n
$$

d. Periksa apakah solusi layak sudah optimum. Pemeriksaan dilakukan dengan menggambarkan garis-garis vertikal dan horizontal yang melewati nilai nol. Jika 
jumlah garis yang terbentuk sama dengan jumlah baris/kolom maka solusi untuk biaya operasi optimal sudah diperoleh.

e. Jika solusi untuk biaya optimal belum diperoleh, kurangkan semua biaya yang tidak dilewati garis dengan biaya terendah, dan tambahkan biaya terendah tersebut pada biaya yang terletak pada perpotongan garis. Biaya lainnya (yang dilewati garis tapi tidak terletak pada perpotongan) tidak berubahKembali ke langkah keempat (d).

2. Menghitung waktu optimal dengan meninimumkan waktu penyelesaian pekerjaan dengan langkah-langkah :

a. Menyusun tabel penugasan. Dimana jenis pekerjaan sebagai baris dan pekerja (karyawan) sebagai kolom.

b. Untuk setiap baris, kurangkan waktu terendah dalam tiap baris pada tabel waktu tertentu dari semua waktu dalam baris tersebut. Secara matematis bisa ditulis, untuk tiap $i$ maka :

$$
C_{i j}-\min \left(C_{i j}\right), j=1,2, \ldots, n
$$

c. Untuk setiap kolom , kurangkan waktu terendah dalam tiap kolom tabel yang diperoleh dari langkah pertama dari semua waktu dalam kolom tersebut. Secara matematis bisa ditulis, untuk tiap $i$ maka :

$$
C_{i j}-\min \left[C_{i j}\right], i=1,2, \ldots, n
$$

d. Periksa apakah solusi layak sudah optimum. Pemeriksaan dilakukan dengan menggambarkan garis-garis vertikal dan horizontal yang melewati nilai nol. Jika jumlah garis yang terbentuk sama dengan jumlah baris/kolom maka solusi untuk waktu penyelesaian optimal sudah diperoleh.

e. Jika solusi untuk waktu penyelesaian optimal belum diperoleh, kurangkan semua waktu yang tidak dilewati garis dengan waktu terendah, dan tambahkan biaya terendah tersebut pada biaya yang terletak pada perpotongan garis. Waktu lainnya (yang dilewati garis tapi tidak terletak pada perpotongan) tidak berubah, Kembali ke langkah keempat (d).

3. Menghitung total biaya dan waktu penyelesaian optimal dengan meggunakan persamaan.

$$
\begin{gathered}
Z=\sum_{i=1}^{m} \sum_{j=1}^{n} C_{i j} X_{i j}=C_{11 j} X_{11}+\ldots \\
+C_{m n} X_{m n}
\end{gathered}
$$

4. Setelah menggunakan persamaan diatas akan diperoleh solusi optimal.

5. Menganalisis pembagian tugas sesuai dari segi biaya atau waktu yang paling optimal.

\section{PEMBAHASAN}

\section{Profile Data}

Data yang diambil dari perusahaan ini yaitu waktu rata-rata yang digunakan dari setiap karyawan untuk menjahit setiap jenis pakaian

\begin{tabular}{|c|c|c|c|c|c|c|c|c|c|c|c|}
\hline & \multicolumn{10}{|c|}{$\begin{array}{c}\text { JENIS PEKERJAAN (waktu dalam } \\
\text { satuan jam) }\end{array}$} \\
\hline & & A & B & C & $\mathrm{D}$ & $E$ & $\mathrm{~F}$ & $\mathrm{G}$ & $\mathrm{H}$ & I & $\mathrm{J}$ \\
\hline \multirow{10}{*}{ 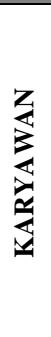 } & Novi & 7 & 7 & 6 & 5 & 7 & 5 & 5 & 3 & 4 & 4 \\
\hline & Ansar & 6 & 6 & 6 & 5 & 7 & 5 & 5 & 3 & 4 & 3 \\
\hline & Rina & 7 & 7 & 4 & 4 & 7 & 5 & 4 & 4 & 4 & 3 \\
\hline & Asma & 7 & 7 & 5 & 3 & 6 & 4 & 4 & 3 & 5 & 3 \\
\hline & Mira & 7 & 7 & 5 & 5 & 6 & 4 & 4 & 3 & 3 & 4 \\
\hline & Fira & 7 & 6 & 6 & 5 & 7 & 3 & 4 & 3 & 4 & 4 \\
\hline & Sari & 7 & 6 & 5 & 3 & 7 & 5 & 5 & 2 & 3 & 4 \\
\hline & Zul & 6 & 6 & 2 & 2 & 6 & 2 & 2 & 2 & 3 & 3 \\
\hline & Rahim & 7 & 7 & 6 & 5 & 7 & 4 & 4 & 3 & 3 & 4 \\
\hline & Nunung & 7 & 7 & 6 & 5 & 6 & 3 & 4 & 2 & 3 & 3 \\
\hline
\end{tabular}
terhitung pada bulan April sampai Mei 2017.

Tabel 4.1 Waktu Penyelesaian Menjahit Setiap Jenis Pakaian

Sumber data: Grand Sony Taylor Makassar bulan april-mei Tahun 2017

Keterangan : $\mathrm{A}=$ Jas, $\mathrm{B}=$ Jas tutup sutra, $\mathrm{C}=$ Pakaian dinas harian $(\mathrm{PDH}), \mathrm{D}=$ Batik, $\mathrm{E}=$ Celana kain, $\mathrm{F}=$ Kemeja press, $\mathrm{G}=$ Kemeja lapis full, $\mathrm{H}=$ Kemeja biasa, $\mathrm{I}=$ Kemeja variasi

Tabel 4.2 Total Waktu Penyelesaian Menjahit Setiap Jenis Pakaian Hungarian.

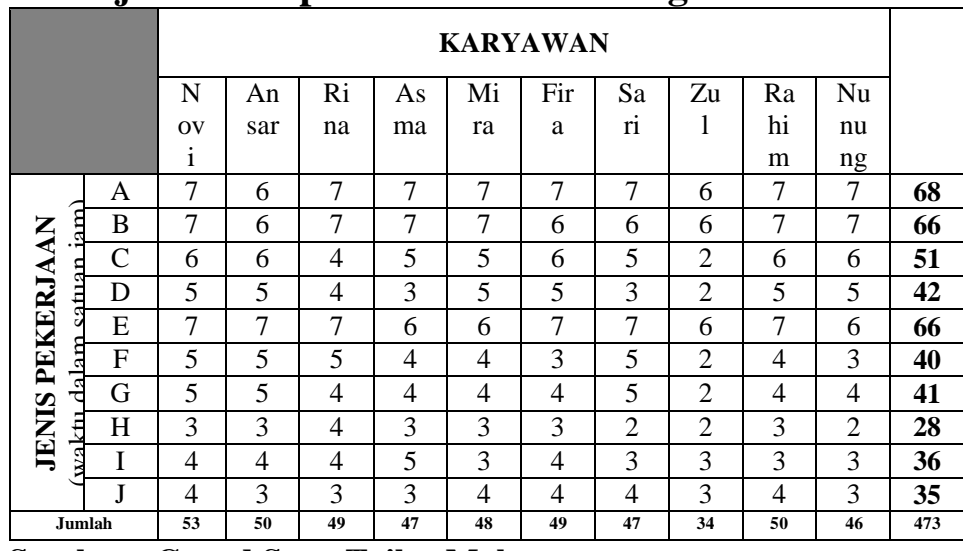

Sumber : Grand Sony Tailor Makassar 
Tabel 4.3. Waktu Penyelesaian Minimum sebelum menggunakan metode Hungarian

\begin{tabular}{|l|l|l|}
\hline \multicolumn{1}{|c|}{ Jenis Pekerjaan } & Pekerja & \multicolumn{1}{c|}{ Waktu } \\
\hline Jas & Ansar & 6 jam \\
\hline Jas Tutup Sutra & Fira & 6 jam \\
\hline PDH & Sari & 5 jam \\
\hline Batik & Asma & 6 jam \\
\hline Celana Kain & Mira & 6 jam \\
\hline Kemeja Press & Nunung & 3 jam \\
\hline Kemeja Lapis Full & Zul & 2 jam \\
\hline Kemeja Biasa & Novi & 3 jam \\
\hline Kemeja Variasi & Rahim & 3 jam \\
\hline Kemeja Variasi Kulit & Rina & 3 jam \\
\hline Total Waktu Minimum & 43 jam \\
\hline
\end{tabular}

Formulasi ke dalam pemrograman linear terlebih dahulu dan diperoleh persamaan sebagai berikut

$$
\text { Minimumkan } Z=\sum_{i=1}^{10} \sum_{j=1}^{10} C_{i j} X_{i j}
$$

Dengan $Z$ menyatakan total waktu penyelesaian menjahit pakaian dan $C_{i j}$ adalah waktu yang diperlukan karyawan untuk menyelesaikan menjahit pakaian dan berdasarkan persamaan diatas dapat diformulasikan kedalam pemrograman linear sebagai berikut :

$Z=7 x_{1,1}+6 x_{1,2}+\cdots+3 x_{10,10}$

Fungsi kendala :

Kendala karyawan :

$$
\begin{gathered}
x_{1,1}+x_{1,2}+\cdots+x_{1,10}=1 \\
x_{2,1}+x_{2,2}+\cdots+x_{2,10}=1 \\
x_{3,1}+x_{3,2}+\cdots+x_{3,10}=1 \\
\vdots \\
x_{6,1}+x_{6,2}+\cdots+x_{6,10}=1
\end{gathered}
$$

Kendala jenis pekerjaan :

$$
\begin{gathered}
x_{1,1}+x_{2,1}+\cdots+x_{10,1}=1 \\
x_{1,2}+x_{2,2}+\cdots+x_{10,2}=1 \\
x_{1,3}+x_{2,3}+\cdots+x_{10,3}=1 \\
\vdots \\
x_{1,10}+x_{2,10}+\cdots+x_{10,10}=1
\end{gathered}
$$

Untuk mengetahui pengoptimalan dengan meminimumkan waktu penyelesaian pekerjaan dengan langkah-langkah sebagai berikut :
1) Menentukan entri terkecil dari setiap baris pada tabel, Matriks waktu untuk masalah ini adalah matriks 10x10.

2) Mengurangi semua entri dalam baris tersebut dengan entri terkecil,

3) Memeriksa apakah setiap kolom telah mempunyai entri nol. Karena ke sembilan kolom matriks telah mengandung entri-entri nol, sehingga hanya perlu mengurangkan 1 (entri terkecil) pada kolom pertama.

Dari hasil pengurangan entri pada setiap baris, terdapat satu kolom yang tidak mempunyai entri 0 yaitu kolom pertama. Sehingga perlu dilakukan pengurangan entri pada kolom pertama.

4) Setelah dilakukan pengurangan pada kolom pertama, maka setiap kolom dan baris sudah mempunyai entri nol. Hasilnya adalah matriks berikut :

5) Melakukan penutupan semua nilai nol dengan menggunakan garis vertikal/horizontal seminimal mungkin. Bila jumlah garis sudah sama dengan jumlah baris/kolom, maka penugasan optimal. Jika jumlah garis belum sama dengan jumlah baris atau kolom, maka dilanjutkan ke langkah selanjutnya.

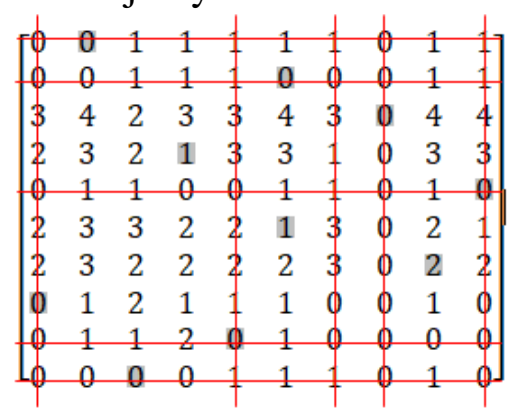

Matriks pada langkah 5 menunjukkan bahwa jumlah garis yang menutupi semua entri 0 sudah sama dengan jumlah baris/kolom, sehingga penugasan telah optimal. Oleh karena itu, penentuan penugasan sudah dapat dilakukan, dimulai dari baris/kolom yang hanya mempunyai satu nilai 0 .

Solusi/keputusan yang diperoleh adalah

$$
\begin{aligned}
X_{1,2}=X_{2,7} & =X_{3,8}=X_{4,4}=X_{5,10}=X_{6,6} \\
& =X_{7,9}=X_{8,1}=X_{9,5}=X_{10,3} \\
& =1
\end{aligned}
$$

Dengan menyesuaikan variabel hasil keputusan, maka diperoleh total waktu 
(minimal) yang dibutuhkan untuk menjahit pakaian tersebut yaitu :

\section{Tabel 4.4. Total waktu optimal menggunakan metode hungarian}

$$
\begin{aligned}
Z= & X_{1,2}+X_{2,7}+X_{3,8}+X_{4,4}+X_{5,10}+X_{6,6}+X_{7,9}+X_{8,1}+X_{9,5} \\
& +X_{10,3} \\
= & 6+6+2+3+6+3+4+3+3+3 \\
= & 39 \mathrm{jam}
\end{aligned}
$$

Untuk pengoptimal biaya produksi setiap jenis pakaian yang dijahit oleh karyawan tidak dapat menggunakan metode Hungarian karena tidak dapat memenuhi syarat penggunaan metode yaitu jumlah pekerjaan tidak sama dengan banyaknya jumlah biaya setiap pakaian. Biaya jahit yang dibayarkan konsumen adalah sebagai berikut :

Tabel 4.5. Biaya Jahit Untuk Setiap Jenis Pakaian

\begin{tabular}{|c|c|}
\hline $\begin{array}{c}\text { Jenis pakaian yang } \\
\text { diproduksi }\end{array}$ & Biaya jahit \\
\hline Jas & $\mathrm{Rp} 1.100 .000,00$ \\
\hline Jas Tutup Sutra & $\mathrm{Rp} 1.250 .000,00$ \\
\hline Pakaian Dinas Harian (PDH) & $\mathrm{Rp} 550.000,00$ \\
\hline Batik & $\mathrm{Rp} 750.000,00$ \\
\hline Celana Kain & $\mathrm{Rp} 300.000,00$ \\
\hline Kemeja Press & $\mathrm{Rp} 400.000,00$ \\
\hline Kemeja Lapis Full & $\mathrm{Rp} 450.000,00$ \\
\hline Kemeja Biasa & $\mathrm{Rp} 300.000,00$ \\
\hline Kemeja Variasi & $\mathrm{Rp} 700.000,00$ \\
\hline Kemeja Variasi Kulit & $\mathrm{Rp} 750.000,00$ \\
\hline
\end{tabular}

Sumber : Grand Sony Tailor Makassar

\section{Keterangan :}

Biaya (ongkos) jahit dapat berubah-ubah jika konsumen membawa model pakaian sendiri.

Setiap karyawan yang memperoleh tugas menjahit pakaian akan menyelesaikannya dengan waktu sesuai tingkat kesulitan menjahit pakaian itu sendiri. Adapun ongkos gaji (upah) yang diperoleh setiap karyawan dalam menjahit setiap jenis pakaian dapat dilihat dari tabel berikut :

Tabel 4.6. Ongkos gaji setiap karyawan untuk menjahit setiap jenis pakaian

\begin{tabular}{|c|c|}
\hline Jenis pakaian yang dijahit & Ongkos kerja karyawan \\
\hline Jas & $\mathrm{Rp} 350.000$ \\
\hline Jas Tutup Sutra & $\mathrm{Rp} 450.000$ \\
\hline PDH & $\mathrm{Rp} 150.000$ \\
\hline Batik & $\mathrm{Rp} 100.000$ \\
\hline Celana Kain & $\mathrm{Rp} 100.000$ \\
\hline Kemeja Press & $\mathrm{Rp} 100.000$ \\
\hline
\end{tabular}
berikut :

Adapun rincian biayanya sebagai

1. Jas $=R p 605 \cdot 000,00+R p 350.000,00=R p$ 955.000,00

2. Jas Tutup Sutra $=\mathrm{Rp} 512.000,00+\mathrm{Rp}$ 450.000,00 = Rp 962.000,00

3. $\mathrm{PDH}=\mathrm{Rp} 282.000,00+\mathrm{Rp}$ $150.000,00=\operatorname{Rp} 432.000,00$

4. Batik = Rp 337.000,00 + Rp $100.000,00=\operatorname{Rp} 437.000,00$

5. Celana Kain $=\mathrm{Rp} \mathrm{129.000,00+Rp}$ $100.000,00=$ Rp 229.000,00

6. Kemeja Press $=\mathrm{Rp} 139.000,00+\mathrm{Rp}$ $100.000,00=$ Rp 239.000,00

7. Kemeja Lapis Full $=\mathrm{Rp} 141.000,00+\mathrm{Rp}$ $150.000,00=$ Rp 291.000,00

8. Kemeja Biasa $=\mathrm{Rp} 106.000,00+\mathrm{Rp}$ 70.000,00 = Rp 176.000,00

9. Kemeja Variasi $=\mathrm{Rp} 338.000,00+\mathrm{Rp}$ $120.000,00=$ Rp 458.000,00

10. Kemeja Variasi Kulit $=$ Rp 340.000,00 + Rp $150.000,00=\operatorname{Rp} 490.000,00$

Tabel 4.7. Total biaya produksi dan keuntungan perusahaan

\begin{tabular}{|c|c|c|c|}
$\begin{array}{c}\text { Jenis Pekerjaan } \\
\text { (menjahit pakaian) }\end{array}$ & Biaya jahit & $\begin{array}{c}\text { Biaya produksi } \\
\text { (bahan + ongkos kerja) }\end{array}$ & Keuntungan \\
\hline 1 stel Jas & $\mathrm{Rp} 1.100 .000,00$ & $\mathrm{Rp} 955.000,00$ & $\mathrm{Rp} 145.000,00$ \\
\hline 1 stel Jas Tutup Sutra & $\mathrm{Rp} 1.250 .000,00$ & $\mathrm{Rp} 962.000,00$ & $\mathrm{Rp} 288.000,00$ \\
\hline 1 stel PDH & $\mathrm{Rp} 550.000,00$ & $\mathrm{Rp} 432.000,00$ & $\mathrm{Rp} 118.000,00$ \\
\hline Batik & $\mathrm{Rp} 750.000,00$ & $\mathrm{Rp} 437.000,00$ & $\mathrm{Rp} 313.000,00$ \\
\hline Celana Kain & $\mathrm{Rp} 300.000,00$ & $\mathrm{Rp} 229.000,00$ & $\mathrm{Rp} \mathrm{71.000,00}$ \\
\hline Kemeja Press & $\mathrm{Rp} 400.000,00$ & $\mathrm{Rp} 239.000,00$ & $\mathrm{Rp} 161.000,00$ \\
\hline Kemeja Lapis Full & $\mathrm{Rp} 450.000,00$ & $\mathrm{Rp} 291.000,00$ & $\mathrm{Rp} 159.000,00$ \\
\hline Kemeja Biasa & $\mathrm{Rp} 300.000,00$ & $\mathrm{Rp} 176.000,00$ & $\mathrm{Rp} 124.000,00$ \\
\hline Kemeja Variasi & $\mathrm{Rp} 700.000,00$ & $\mathrm{Rp} 458.000,00$ & $\mathrm{Rp} 242.000,00$ \\
\hline Kemeja Variasi Kulit & $\mathrm{Rp} 750.000,00$ & $\mathrm{Rp} 490.000,00$ & $\operatorname{Rp} 260.000,00$ \\
\hline
\end{tabular}

Keuntungan perusahaan diperoleh dari biaya jahit yang dibayarkan oleh konsumen secara umum diluar dari biaya bahan dan gaji karyawan.

Jadi, untuk biaya yang dikeluarkan oleh perusahaan dalam setiap bulannya dapat diformulasikan kedalam pemrograman linear sebagai berikut : 


$$
Z=\sum_{j=1}^{10} X_{j}
$$

Dengan $Z$ menyatakan total biaya produksi pakaian dan $X_{i}$ adalah biaya yang dikeluarkan perusahaan untuk menmproduksi dalam setiap jenis pakaian dan berdasarkan persamaan diatas dapat diformulasikan kedalam pemrograman linear sebagai berikut :

$$
\begin{gathered}
Z=X_{1}+X_{2}+X_{3}+X_{4}+X_{5}+X_{6}+ \\
X_{7}+X_{8}+X_{9}+X_{10}
\end{gathered}
$$

Fungsi kendala :

Kendala biaya :

$X_{1}=1$

$X_{2}=1$

$X_{3}=1$

$X_{4}=1$

$X_{5}=1$

$X_{6}=1$

$X_{7}=1$

$X_{8}=1$

$X_{9}=1$

$X_{10}=1$

Tabel 4.8. Total biaya produksi sesuai

\begin{tabular}{|c|c|c|}
\hline Jenis Pekerjaan & Karyawan (pekerja) & Jumlah biaya \\
\hline Jas & Ansar & Rp $955.000,00$ \\
\hline Jas Tutup Sutra & Sari & Rp $962.000,00$ \\
\hline PDH & $\mathrm{Zul}$ & $\operatorname{Rp} 432.000,00$ \\
\hline Batik & Asma & Rp $437.000,00$ \\
\hline Celana Kain & Nunung & $\operatorname{Rp} 229.000,00$ \\
\hline Kemeja Press & Fira & $\operatorname{Rp} 239.000,00$ \\
\hline Kemeja Lapis Full & Rahim & $\operatorname{Rp} 291.000,00$ \\
\hline Kemeja Biasa & Novi & Rp $176.000,00$ \\
\hline Kemeja Variasi & Mira & $\operatorname{Rp} 458.000,00$ \\
\hline Kemeja Variasi Kulit & Rina & $\operatorname{Rp} 490.000,00$ \\
\hline \multicolumn{2}{|c|}{ Total biaya } & Rp 4.669.000,00 \\
\hline
\end{tabular}
penugasan optimal berdasarkan waktu penyelesaian optimum.

\section{Keterangan :}

Total biaya produksi terhitung dari seluruh biaya produksi yang dibayarkan konsumen untuk 10 jenis pakaian.

Untuk memperoleh biaya produksi optimum tidak dapat dilakukan dengan menggunakan metode Hungarian karena biaya yang dikeluarkan untuk memproduksi pakaian akan tetap sama jika dikerjakan dengan karyawan yang berbeda-beda. Jadi, biaya produksi optimum diperoleh untuk 10 jenis pakaian adalah tetap yaitu Rp 4.669.000,00.

\section{KESIMPULAN}

Dari hasil penelitian, setelah menggunakan metode Hungarian diperoleh waktu penyelesaian menjahit pakaian pada Grand Sony Tailor yaitu 39 jam, dimana terjadi efisiensi waktu sebanyak 4 jam jika dibandingkan waktu penyelesaian sebelum menggunakan metode Hungarian yaitu selama 43 jam. adapun untuk biaya produksi yang dikeluarkan perusahaan melihat dari penempatan tugas karyawan dengan waktu penyelesaian optimum yaitu Rp 4.669.000,00dengan keuntungan perusahaan $\mathrm{Rp}$ 1.880.000,00 dalam menyelesaikan 10 jenis pakaian.

\section{DAFTAR PUSTAKA}

[1]Anton, Howard,dan Rorres. 1987. Penerapan Aljabar Linear. Penerbit Erlangga. Jakarta.

[2] Aminuddin. 2002. Prinsip-Prinsip Riset Operasi. Penerbit Erlangga. Jakarta.

[3] Bambang Yuwono dan Putri Nur Istiani. 2007. Bahan Kuliah Riset Operasional. UPN “Veteran” Yogyakarta. Yogyakarta.

[4] Didi Raharjo. 2010. Proses Optimasi dn Idealisasi Masalah Penugasan Multi Objective Menggunakan Metode Hungarian. Fakultas Matematika dan Ilmu Pengetahuan Alam.

[5] Halim. 2013. AL Qur'an dan Terjemahan. Surabaya. Yayasan Penyelenggara Penerjemah/Penafsir AL Qur'an.

[6] Jimi Priyo Assiddiq. 2014. Optimalisasi Pembagian Pekerja Bangunan Menggunakan Metode Hungarian. Jurusan Manajemen Fakultas Ekonomi.

[7] Maslihah, Siti. 2014. Optimasi Masalah Penugasan. JPM IAIN Antasari. Vol. 01 No. 2. Semarang.

[8] Prawirosentono, S. 2005. Riset Operasi dan Ekonofisika. PT. Bumi Aksara. Jakarta

[9] Siswanto.2002. Operations Research Jilid I.PenerbitErlangga.Jakarta.

[10] Siti Nurasyiah dan Toto Sugiharto. 2004. Analisis Penjadwalan Ulang Penerbangan Pesawat Boeing 747 Berdasarkan Waktu Tunggu Bandara Menggunakan Metode Hungarian.Fakultas Ekonomi Universitas Gunadarma. 
JURNAL MSA VOL. 6 NO. 1 ED. JAN-JUNI 2018

[11] Soemartojo, N. 1997. Program Linear. Depdikbud Direktorat Jenderal Pendidikan Dasar dan Menengah. Jakarta.

[12] Taha, Hamdy A. 1996. Riset Operasi Jilid I. Penerbit Binarupa Aksara. Jakarta

[13]Wijaya, Andi. 2011.PengantarDasarOperasi. Penerbit MitraWacana Media. Jakarta. 